\title{
Virgin Islands, British
}

National Cancer Institute

\section{Source}

National Cancer Institute. Virgin Islands, British. NCI Thesaurus. Code C17653.

A group of islands between the Caribbean Sea and the North Atlantic Ocean, east of the US Virg in Islands. 